\title{
Does Manager Turnover Improve Firm Performance? Evidence from Dutch Soccer, 1986-2004
}

\author{
Bas ter Weel
}

Published online: 18 January 2011

(C) The Author(s) 2011. This article is published with open access at Springerlink.com

\begin{abstract}
This research examines the impact of manager turnover on firm performance using information from the Dutch soccer league in the period 1986-2004. The main advantage of using sports data is that both manager characteristics and decisions and firm outcomes are directly observable. Both difference-in-difference and 2SLS estimates suggest no statistically significant improvements in performance after manager turnover, whereas previous research based on publicly traded firm data has found positive but very small effects of manager turnover on performance. The estimates confirm previous research using soccer data. In addition, estimates suggest that manager quality does not seem to matter in predicting turnover. These estimates are compared and contrasted with studies using publicly traded firm data and studies using soccer data.
\end{abstract}

Keywords Manager turnover - Firm performance $\cdot$ Economics of sports

JEL Classification $\quad \mathrm{J} 21 \cdot \mathrm{J} 24 \cdot \mathrm{J} 44$

\section{Introduction}

This research examines the impact of manager turnover on firm performance using information from the Dutch soccer league in the period 1986-2004. There have been

B. ter Weel $(\varangle)$

CPB Netherlands Bureau for Economic Policy Analysis,

The Hague, The Netherlands

e-mail: b.ter.weel@cpb.nl

B. ter Weel

UNU-MERIT, Maastricht University,

Maastricht, The Netherlands 
many studies addressing the impact of manager turnover on firm outcomes but the estimates presented in these studies turn out to be sensitive to different measures of performance, with outcomes being relatively well-measured for publicly traded firms and largely unknown for small firms and firms without stock-market quotations. In addition, the timing of manager turnover is not always clear and bad performing managers are sometimes transferred to other positions within the same firm without the reasons for such transfers becoming public. In many instances, manager background and personal characteristics are also unknown but likely to be crucial for firm outcomes and turnover (e.g., Malmendier and Tate 2009). Finally, manager decisions concerning firm investments, employment and strategy are often unobserved but important for firm outcomes and manager performance (e.g., Bertrand and Schoar 2003 and Bloom and Van Reenen 2007). The main conclusion from the empirical literature addressing the impact of manager turnover on business firm performance is that the magnitude of the effects of management changes is statistically significant, but that the economic significance is small in terms of performance improvements.

The main reasons for turning to sports data in addressing the effects of manager turnover on firm outcomes are fivefold. First, firm performance can be measured directly and on a weekly basis, whereas reliable business firm performance is often only measured indirectly through financial statements and on a yearly basis. The main advantage of having information on firm outcomes in short time intervals is that managers are often released during the year. So, for business firm data the years prior to manager resignation have to be compared to the years after resignation, with the most interesting year of resignation being lost for the empirical analysis. The advantage of using weekly data is that the period is short enough to isolate the manager effect on firm outcomes, whereas annual information on firm performance is likely to be subject to other (hard to measure) factors as well. Second, the performance measure is well-defined: win, draw or loss. In contrast, different business firms rely on different accounting measures, which can make performance look different under different schemes. Third, managers' decisions concerning firm investments are directly observed by means of the number of players bought and sold and become effective immediately, whereas a business manager's long-term strategies are often becoming effective after much longer periods of time. Fourth, the soccer league comprises one relatively homogeneous industry, which makes the comparison across firms easier. Finally, important manager characteristics are available, such as directly observable past performance in management, experience as a worker (soccer player), the type of player the manager used to be (offensive or defensive player), and the history of being a top soccer player measured by whether or not the manager has played for his country. For business CEOs such information on firm-specific and general human capital and working experience is mostly unavailable.

The empirical results in this paper suggest that manager turnover is not followed by significant increases in firm outcomes. In particular, a difference-in-difference analysis reveals that firms that sack managers do even worse compared to those in a control group whose performance is also falling substantially for some period of time. The results are robust for different definitions of the control group and suggest that the small positive effects of manager turnover on firm performance found in the business literature are unlikely to be present in the sample of soccer firms. It is also shown that 
these estimates are not specific to the Netherlands and seem to apply to other major soccer leagues in Europe as well (England, Germany, Italy and Spain). These estimates are confirmed by reviewing the literature on the effects of manager turnover on soccer team performance for these countries. In addition, analysis of the determinants of manager turnover suggests that manager investments (measured by the number of players bought) and the remaining contract length at the time of the dip are the best predictors for forced turnover. When managers have invested more, in terms of the number of players they bought, they are more likely to be sacked during performance dips and when they have a longer period left on their current contract they are less likely to be fired. There is also a small effect of tenure, with more experienced managers having a lower probability to be fired. Finally, firm expectations and deviations from expected performance contribute significantly to manager turnover. Using this information, 2SLS estimates of forced resignations on performance improvements after release suggest a positive but insignificant effect of manager turnover on firm outcomes when comparing actual events of manager turnover to several definitions of the control group of firms.

The plan of the paper is the following. Section 2 presents the theoretical background. Section 3 presents the most salient features of the data, the construction of the measures used in the empirical analysis and a number of descriptive statistics. Section 4 contains the estimates: (i) OLS and 2SLS estimates of the effects of turnover on performance and a comparison with other soccer leagues, and (ii) cross-sectional estimates of manager characteristics on the probability of being released. Section 5 relates the estimates of this study to the evidence found using publicly traded business firm data and to the evidence from other recent analyses using soccer data to assess firm performance after manager release. Section 6 concludes.

\section{Theoretical Background}

To determine the effects of manager turnover on firm outcomes it is important to assess whether individual managers are central in bringing about differences in firm performance. If managers matter there are two possible scenarios. First, a manager will impose his style on the company. Whether this will be more likely to materialize in well-performing or under-performing firms depends on corporate control. In sports corporate control is often very strong, with the owners and president prominently present at match days, so more strongly governed companies will be more likely to select managers with a particular style. In general, firms that do relatively well are characterized by a more prominently board of directors and owner. ${ }^{1}$ An implication of this theory is that managers are willing to work in only those companies in which they can exert influence on employees.

An alternative view is that managers may be hired because of their comparative advantages in specific areas and firms optimally choose those managers who are best

\footnotetext{
1 Malmendier and Tate (2009) present evidence that award-winning managers subsequently under-perform because they spend more time doing other things than managing their company. This effect is particularly strong in firms with relatively weak corporate governance.
} 
assigned to the current needs of the firm. In this case the individual manager effect could only be identified if a firm's strategy is time varying. If not, the style of the new manager would only be a continuation of the outgoing one. Bertrand and Schoar (2003, p. 1197) speculate on the importance of the two effects and conclude that their results "appear to suggest that better governed firms select managers with performance-enhancing styles and as such might point toward efficiency implications of the managerial heterogeneity". Below it will be shown that in case of the Dutch soccer league the firms' optimal strategies do not seem to fluctuate to a large extent over time because their league positions remain fairly stable over time. This suggests that firms' strategies are relatively time invariant and the characteristics of the new manager would likely be very much like the outgoing one.

If managers do not matter for differences in performance across firms and quality does not vary across managers, the only observed performance change following turnover would be mean reversion. This process will be characterized by a short-term increase in performance when the new manager is in place but no long-term gains are to be expected. In this world managers will be forced out of the firm because of the string of bad results that can be attributed to bad luck, not bad performance, or circumstances at the firm not directly related to the manager's performance. In such a view there is a market for managers in which all have to exert a certain level of costly effort. To ensure a critical level of effort firms have to be able to threaten to fire managers. In equilibrium, all managers are identical and supply the same level of effort. To maintain the equilibrium effort level boards of directors fire managers to make the other managers exert the desired level of effort. Some evidence in favour of this theory is presented by Khanna and Poulson (1995) who compare management in firms that go into liquidation by filing for "Chapter 11" with management in firms doing fine over a period up to 3 years before the "Chapter 11" filing. Their estimates suggest that managers in both samples make similar decisions and that managers of financially distressed firms are not taking value-reducing actions to harm the firm or its shareholders. In this setting managers who are fired are used as scapegoats to lift the level of performance up to mean performance.

\section{Data, Measures and Descriptive Statistics}

In this section the most salient details about the dataset used for the empirical analysis are discussed. In addition, a number of core measures are constructed and descriptive statistics are presented to obtain a first glance of the estimates presented in Sect. 4.

\subsection{Teams and Turnover Measures}

The data consist of teams from the highest professional Dutch soccer league (Eredivisie). Information on team performance is available for 18 seasons in the period 1986-2004. Teams included are present in the Eredivisie for at least 50 percent of all seasons. Every year the league consists of 18 teams of which the team finishing last is relegated and the teams finishing 16th and 17th are playing a playoff competition 


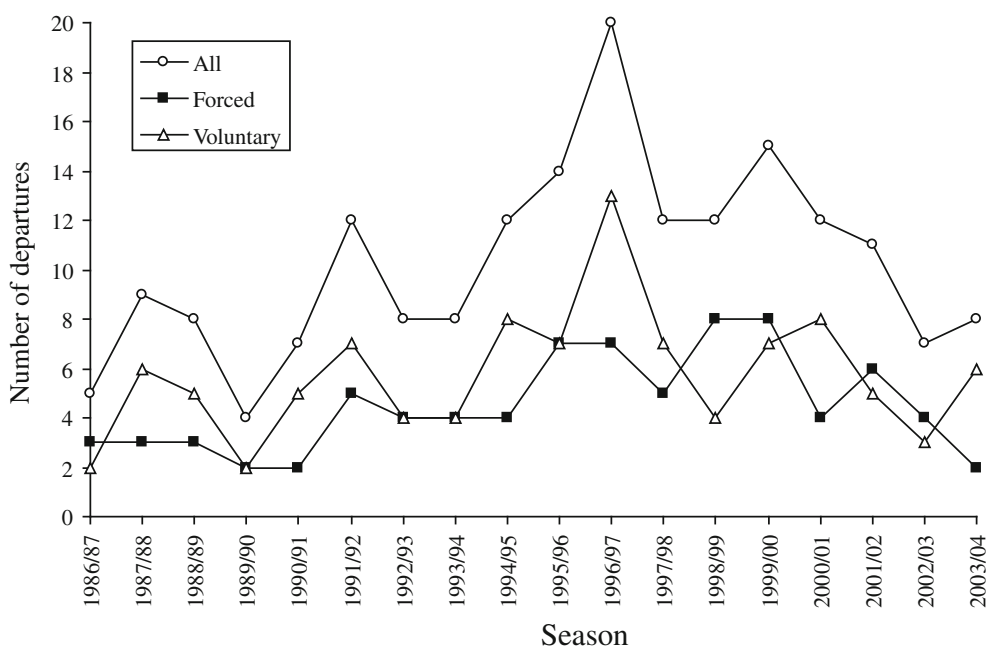

Fig. 1 Management turnover in Dutch soccer, 1986-2004.

Note The horizontal axis measures time in terms of soccer seasons. Seasons start in August and end in May. So, 1988/89 means the soccer season from August 1988 until May 1989. The vertical axis displays the number of departures. The total number of departures for the period 1986-2004 is equal to 184. The number of forced resignations equals 81 and the number of voluntary leaving managers is 103

with teams from the second professional league (Eerste Divisie). The information is obtained from Infostrada BV, a private firm collecting sports data.

The sample for empirical analysis consists of 19 teams with a total number of 184 manager turnovers of which 81 have been forced and 103 have been the result of separations after the manager's contract expired. This implies a relatively steep hazard rate for managers, since during the average season over 50 percent of the teams are replacing managers; 44 percent of all separations have been forced. The data on manager turnover are collected by searching through articles about the turnover in the weekly Dutch soccer magazine Voetbal International. In addition, Infostrada BV gave access to their archive in which the exact date of manager release and manager appointment is registered. This archive has been used to determine the dates of commencement of employment and termination of the contract. On the basis of the information in the articles from the magazine Voetbal International it is decided whether turnover has been voluntarily or forced.

Figure 1 presents the number of resignations by season and the subdivision into forced and end-of-contract separations. Although there appears to be a peak in the number of manager separations in the 1996/97-season, a $\chi^{2}(18)$ test for uniformity by season across teams does not exceed the 25 percent critical value of 26.0. In addition, the $\chi^{2}(18)$ test for uniformity across teams suggests the same. ${ }^{2}$

\footnotetext{
2 A potential concern with non-uniformity is that big firms are harsher towards managers, while the performance of relatively small firms is more volatile. This would lead to concentration of resignations among big firms and performance dips among small firms, which would cast doubt on the construction of valid control groups.
} 


\subsection{Performance Measures}

Usually, performance is measured as the number of points, which is a strictly non-decreasing measure during a season. In illustrating performance fluctuations it is preferred to construct a performance measure that decreases when performance deteriorates. In addition, manager turnover often takes place during a season, so the period of time is often shorter than a full season. An alternative would be to measure performance as points earned per game, so that performance can vary from 0 to 1 and 3. The drawback of this alternative is that performance may get too volatile to be altogether informative and complicate the empirical analysis considerably. The way performance is defined in this paper is a performance measure that is related to points per game obtained on average during the last four games. ${ }^{3}$ This way, a performance measure is obtained that goes down in case of a series of bad games, but at the same time is not too sensitive to an occasional loss (win) in a series of wins (losses).

In order to evaluate whether performance is good or bad, a comparison with some "ordinary" performance level has to be made. The measure of this performance level is based on the average number of points obtained during the current season by a typical manager. This is a relatively short-term performance measure that circumvents the issues of (large) changes in the squad's composition and adjustment of annual budgets in between seasons. It is also more appropriate compared to using league positions at different points in time, since a team's league position depends more on the performance of other team than the average number of points obtained.

Finally, the relative performance of a team at a particular point in time as the fourgame point average divided by the manager's seasonal average of points per game has been computed. Performance defined in this way provides insight into the performance of a team relative to season average. Whenever performance exceeds (falls below) unity, the team performs at a higher (lower) level than the ordinary level. An advantage of this performance measure is that it has the same interpretation for all teams and can be used to present normalized performance levels and performance dips.

Appendix 1 presents more information about the performance over time of each of the 19 teams in the data. The most striking result is that firm performance is fairly constant over time. This time-invariant trend in performance would suggest that the firms' are appointing new managers with similar styles to follow up their leaving managers.

\subsection{Performance Dips}

Figure 2 presents the performance levels before and after the resignation dates for forced and voluntary resignations. On the horizontal axis the time before and after resignation is measured. At time $t-1$ the outgoing manager is in charge of his last game. At point $t$ (in between matches) the managers resigns and at $t+1$ the manager has resigned and another manager has taken over. To evaluate the effectiveness of manager turnover, a comparison between pre- and post-turnover performance is

\footnotetext{
${ }^{3}$ Performance levels defined by a moving average during the last three or five games do not qualitatively alter the results.
} 


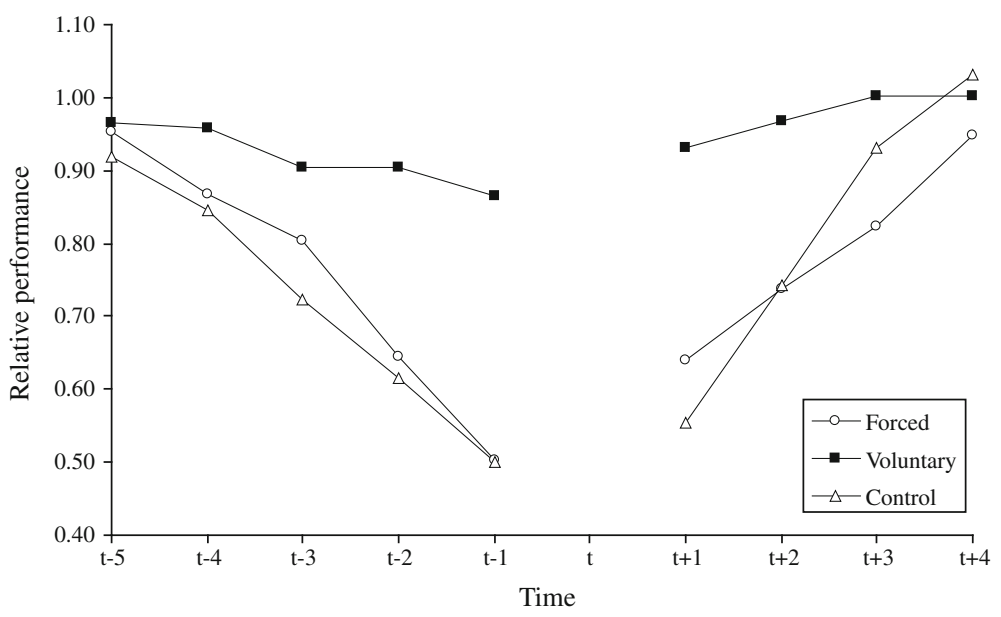

Fig. 2 Firm performance around management turnover.

Note The horizontal axis measures time in terms of time ahead of the dip (from $t-5$ to $t-1$ ) and time after the dip (from $t+1$ to $t+4$ ). At time $t$ (in between matches) the old manager is sacked and at time $t+1$ he is replaced and the new manager has his first result. The vertical axis displays relative performance, which is measured as a moving average of four game results divided by the season's average to make possible comparison across teams. This picture is based on 81 forced resignations in the period 1986-2004, 103 voluntary departures and 212 performance dips that serve as a control group. The construction of the control group is explained in Sect. 3.4

required. In the business literature it is common to select periods in between three and 5 years prior to and after resignation to assess the effects of manager turnover on firm outcomes. Here a period of four games is selected as the period of analysis. This period of time seems to be sufficiently long to allow for a substantial effect on the performance measure.

Figure 2 suggests that manager turnover as a result of forced resignations is accompanied by a substantial fall in firm performance. It is also followed by a steep increase in performance after the manager has left. By contrast, voluntarily leaving managers do not seem to impact firm performance to a large extent, although there seems to be a slight rise in performance after the manager has left. Briefly investigating instant success by looking whether the first game after the manager has left makes a difference in case of forced resignations learns that almost 30 percent of the new managers have won their first game. In case of voluntary turnover this equals 49 percent of all new managers.

\subsection{Construction of Control Groups}

Barber and Lyon (1996) suggest a matching method to construct comparison firms and a control group of firms to which the performance dips can be compared. ${ }^{4}$ Using

\footnotetext{
4 An important advantage of the present data is that only one industry is analyzed. When analyzing more industries each sample firm has to be matched to comparison firms within the same industry, which is sometimes hard to achieve. See e.g., Huson et al. (2004, pp. 247-248).
} 
their line of reasoning the control group to against which to measure firm performance in case of forced resignations is constructed as follows. First, the performance at $t-4$ can be at most 10 percent above its long-run average during a season. Second, performance has to decline by at least 25 points during the next four games. Third, at $t-1$ the performance level is at 75 percent or less of the seasonal average. Of course, these dips and actual resignations are mutually exclusive. Bruinshoofd and Ter Weel (2003) apply a similar method to identify control groups, using a variety of different but related requirements. In particular, they test the robustness of the second (between 15 and 35 percent) and third (up to 65 percent or less) requirements and find no qualitative differences in the conclusions to be drawn from relating the control groups to the actual observed turnover events. In the empirical application there will be analyses of three different control groups to see whether the construction is sensitive to the outcomes of the difference-in-difference and 2SLS estimates.

The number of performance dips identified in this way equals 212 . A $\chi^{2}(18)$ test for uniformity by season across teams never exceeds the 10 percent critical value of 26.0, suggesting that all firms face performance dips to a roughly similar extent. Figure 2 presents the performance dip of the control group, which mirrors to a large extent the performance dips in which managers have been sacked as a result of poor performance.

\subsection{Manager Characteristics}

Table 1 lists the means and standard deviations of manager characteristics available in the data. These moments will be used to investigate whether differences in manager characteristics are able to explain the probability of manager turnover. The columns distinguish between sacked managers, voluntarily leaving managers and managers facing performance dips. There do not seem to be major differences in the means of the manager characteristics available. The average age of soccer managers is around 47 and their level of experience is around 17 years. For managers facing performance dips both age and experience seem to be a little higher, but the standard deviations are sizeable.

The next three manager characteristics are related to their careers as soccer players. Some 75 percent of the managers have had a career in professional soccer. Half of that population has played at the top level, which is measured by a dummy variable equalling one if a manager has played for his country. Finally, around 20 percent of the population used to be playing as an attacker. The latter variable could be used as an indicator for more risky behaviour in management compared to managers who used to be defensive players.

The next two variables are related to tenure with the club and the number of spells a manager has had during his career. Concerning the number of spells, the data suggest that managers with more spells are more likely to be forced out. In addition, they seem to have lower levels of tenure.

The number of players bought is a variable measuring the trust a board has in its manager to do (long-term) investments. If a board would not have much confidence in its manager it would not allow the manager to sign as many new players as a manager which they highly trust. Another indicator of investments would be the amount of money spent by the manager. Unfortunately, these figures are not available. It is likely 
Table 1 Manager characteristics

\begin{tabular}{|c|c|c|c|}
\hline & $\begin{array}{l}\text { Forced } \\
\text { resignations }\end{array}$ & $\begin{array}{l}\text { Voluntary } \\
\text { resignations }\end{array}$ & $\begin{array}{l}\text { Control } \\
\text { group }\end{array}$ \\
\hline \multirow[t]{2}{*}{ Age (years) } & 46.875 & 46.928 & 47.044 \\
\hline & $(6.260)$ & $(7.174)$ & $(5.899)$ \\
\hline \multirow[t]{2}{*}{ Experience as a manager (years) } & 17.448 & 16.532 & 18.472 \\
\hline & $(6.917)$ & $(7.541)$ & $(6.707)$ \\
\hline \multirow[t]{2}{*}{ Playing career as soccer player (dummy variable) } & 0.790 & 0.767 & 0.675 \\
\hline & $(0.410)$ & $(0.425)$ & $(0.470)$ \\
\hline \multirow[t]{2}{*}{ Played for country (dummy variable) } & 0.370 & 0.350 & 0.311 \\
\hline & $(0.486)$ & $(0.479)$ & $(0.464)$ \\
\hline \multirow[t]{2}{*}{ Attacking player (dummy variable) } & 0.247 & 0.194 & 0.212 \\
\hline & $(0.434)$ & $(0.398)$ & $(0.410)$ \\
\hline \multirow[t]{2}{*}{ Number of spells during career } & 1.728 & 1.680 & 1.538 \\
\hline & $(0.962)$ & $(1.012)$ & $(0.845)$ \\
\hline \multirow[t]{2}{*}{ Tenure with club (days) } & 539.457 & 550.854 & 640.15 \\
\hline & $(376.378)$ & $(654.473)$ & $(638.270)$ \\
\hline \multirow[t]{2}{*}{ Total number of players bought during spell at one club } & 10.247 & 10.155 & 9.307 \\
\hline & $(4.170)$ & $(4.021)$ & $(3.637)$ \\
\hline \multirow[t]{2}{*}{ Remaining contract length when leaving (days) } & 336.272 & 23.272 & 635.127 \\
\hline & $(372.606)$ & $(101.724)$ & $(592.671)$ \\
\hline$n$ & 81 & 103 & 212 \\
\hline
\end{tabular}

The numbers in the table are means with standard deviations reported in brackets. When necessary, the unit of observation is reported in brackets in the first column

though that the number of players bought by the manager is correlated with the amount of money spent. The numbers suggest that managers forced out have generally bought more players than the other managers, which could suggest that pressure is higher when more investments have been made. Frick and Simmons (2008) find evidence for German soccer teams that higher quality managers make better investments, which is consistent with the measure used here.

Finally, the remaining contract length serves as an indicator of the costs involved in sacking a manager. Usually, a manager receives the remaining salary left on his contract when he is forced out or a reflection of that pay, which could serve as a burden to firm to not sack the manager. Comparing the forced resignations with the control group indeed suggests a large difference in the remaining length of the contract during performance dips.

\section{Results}

The estimation results are presented in four parts. First, the performance dips will be considered by presenting a set of difference-in-difference estimates. Second, the effects of manager characteristics are taken into account. Third, firm's expectations are considered. Fourth, a set of 2 SLS results is presented to try to adjust for the case in which the manager would not have been released. 


\subsection{Performance Dips}

This section presents a number of difference-in-difference estimates. It also compares the outcomes to an analysis of manager turnover in four other major soccer leagues in Europe in the season 2000/1 and a somewhat more detailed analysis for Germany.

\subsubsection{Difference-in-Difference Estimates}

Let $Y_{w, x}$ denote the four-game performance average where the manager is still in place after time $t$ (with $x>t$ ) and let $Y_{w,-x}$ denote the four-game performance average of the same manager before time $t+1$ (at time $t$ the "old manager" is still in place). When the manager is forced out $Y_{v, x}$ and $Y_{v,-x}$ are defined in a similar way. Next, $A=1$ for teams facing a performance dip, and $A=0$ otherwise. Finally, when the manager is forced out $B=1$, and $B=0$ otherwise. The impact of manager turnover on firm outcomes $y$ is then defined as $y=E\left(Y_{v, x}-Y_{v,-x} \mid B=1, A=1\right)-E\left(Y_{w, x}-Y_{w,-x} \mid B=0, A=1\right)$. This expression defines the difference-in-difference estimator of the four-game performance average between the "treatment" (managers who are forced to resign) and the "control" (managers who are facing a performance dip but are allowed to continue their work) group in period $x$ after the performance dip relative to period $-x$ before the dip.

Panel A in Table 2 reports the difference-in-difference estimation results. The first column compares forced turnovers with the control group for all resignations observed. What is clear is that performance increases after one period are significant but that the new manager performs worse compared to the control group in the next three periods he is in charge. In the popular media and soccer magazines the release of a manager and the appointment of a new manager is often surrounded with a lot of attention and the suggestion is often made that there will be a "shock effect". This effect is expected to make the team perform better and justifies the release of the previous manager. The estimates in Panel A suggest that there is most likely a very short-run shock effect picked up by the popular media, but that this effect is not lasting very long, in fact only one game. The medium and long-run effects of appointing a new manager do not seem to be very clear, and if anything are not positive.

Panel B in Table 2 presents similar results for managers with an above average level of experience (more than 18 years). Finally, Panel $\mathrm{C}$ in Table 2 presents the difference-in-difference estimates for managers who have been top soccer players in the past. Top players are defined as those players who have represented their country in international matches. The choice for these two groups is motivated by the fact that if a team performs below average, a manager who is relatively experienced will be more able to solve problems and turn things around. In addition, managers with topplaying careers are more likely to be respected by the current players because of their achievements, so their appointment will be well received by the players, which in turn is expected to have a positive effect on performance. The results, presented in Panel B and $\mathrm{C}$, suggest similar outcomes compared to the results displayed in Panel A. There seems to be an immediate effect, which goes away relatively fast. What is interesting to observe is that more experienced managers and managers with a top-player career do 
Table 2 Difference-in-difference estimates of team performance around management turnover

\begin{tabular}{|c|c|c|c|}
\hline & $\begin{array}{l}\text { Baseline control } \\
\text { group (Four-game } \\
\text { decline of max. } 25 \\
\text { percent, } \\
\text { performance at } \\
\text { min. } 75 \text { percent of } \\
\text { season's average) }\end{array}$ & $\begin{array}{l}\text { Control group } 2 \\
\text { (Four-game } \\
\text { decline of max. } 25 \\
\text { percent, } \\
\text { performance at } \\
\text { min. } 65 \text { percent of } \\
\text { season's average) }\end{array}$ & $\begin{array}{l}\text { Control group } 3 \\
\text { (Four-game } \\
\text { decline of max. } 35 \\
\text { percent, } \\
\text { performance at } \\
\text { min. } 65 \text { percent of } \\
\text { season's average) }\end{array}$ \\
\hline \multicolumn{4}{|c|}{ Panel A: all cases } \\
\hline $\mathrm{T} 1$ & $0.082(0.052) *$ & $0.086(0.050) *$ & $0.090(0.052) *$ \\
\hline $\mathrm{T} 2$ & $-0.035(0.083)$ & $-0.057(0.081)$ & $-0.051(0.076)$ \\
\hline $\mathrm{T} 3$ & $-0.188(0.098) *$ & $-0.189(0.089) * *$ & $-0.182(0.078) * *$ \\
\hline $\mathrm{T} 4$ & $-0.107(0.060) *$ & $-0.153(0.062) * *$ & $-0.159(0.060) * *$ \\
\hline \multicolumn{4}{|c|}{ Panel B: experienced managers } \\
\hline $\mathrm{T} 1$ & $0.098(0.045) * *$ & $0.087(0.045) *$ & $0.081(0.045) *$ \\
\hline $\mathrm{T} 2$ & $-0.116(0.069) *$ & $-0.102(0.062) *$ & $-0.100(0.059) *$ \\
\hline $\mathrm{T} 3$ & $-0.177(0.091) *$ & $-0.132(0.068) *$ & $-0.122(0.061) * *$ \\
\hline $\mathrm{T} 4$ & $-0.165(0.098) *$ & $-0.141(0.096) *$ & $-0.135(0.090) *$ \\
\hline \multicolumn{4}{|c|}{ Panel C: former top players } \\
\hline $\mathrm{T} 1$ & $0.043(0.052)$ & $0.041(0.047)$ & $0.038(0.043)$ \\
\hline $\mathrm{T} 2$ & $-0.176(0.067) * *$ & $-0.126(0.054) * *$ & $-0.108(0.050) * *$ \\
\hline $\mathrm{T} 3$ & $-0.236(0.115) * *$ & $-0.211(0.103) * *$ & $-0.192(0.099) *$ \\
\hline $\mathrm{T} 4$ & $-0.234(0.143) *$ & $-0.203(0.118) *$ & $-0.186(0.109) *$ \\
\hline \multicolumn{4}{|c|}{ Panel D: other countries } \\
\hline $\mathrm{T} 1$ & $0.042(0.032)$ & $0.051(0.026) * *$ & $0.050(0.025) * *$ \\
\hline $\mathrm{T} 2$ & $0.005(0.033)$ & $0.013(0.032)$ & $0.014(0.031)$ \\
\hline $\mathrm{T} 3$ & $-0.072(0.038) *$ & $-0.063(0.032) * *$ & $-0.062(0.031) * *$ \\
\hline $\mathrm{T} 4$ & $-0.098(0.048) * *$ & $-0.089(0.046) *$ & $-0.090(0.046) * *$ \\
\hline
\end{tabular}

Robust standard errors are reported in brackets. A * indicates that a coefficient is significant at the 10 percent level, ** at the 5 percent level. TX refers to the difference in performance between $t+X$ and $t-X$ for a specific group, differenced between the, at the top of the columns and panels, indicated groups. Experienced managers are defined as managers with above average (18 years) levels of experience. Former top players are defined as players who have represented their country in international games. The other countries are England, Germany, Italy and Spain (details about these countries are given in Sect. 4.1.2)

worse than relatively less experienced managers and managers who have had no topplayer career, since the coefficients for the second to fourth period are generally more negative in Panel B and C than they are in Panel A. These estimates seem to suggest that arguments in favour of the appointment of more experienced and well-respected managers do not help the firm to turn things around more effectively.

To assess the robustness of these results, the second column presents the performance difference for a control group in which performance is allowed to fall to 65 percent of the season's average to see whether the construction of the control group is relatively sensitive to the results. The number of dips in this case is equal to 243 . Finally, the difference-in-difference estimates for the difference between forced and a 
third control group are presented in the third column. Here, performance is allowed to fall to 65 percent of the season's average and the decline during the four-game period prior to the dip is allowed to be 35 percent. Now, the number of performance dips is equal to $269 .^{5}$ Although the coefficients change somewhat by constructing different control groups, the qualitative results from this exercise do not change.

\subsubsection{Are these Results Specific to the Netherlands?}

For the season 2000/01 data about manager separations have been collected from the English (Premier League), the German (1.Bundesliga), the Italian (Serie A) and Spanish (Primera División) soccer leagues. The total number of separations during this season in the Netherlands equals 12 (4 forced, 8 voluntary separations). These numbers are $10(6,4)$ for England, $10(7,3)$ for Germany, $14(9,5)$ for Italy, and 15 $(9,6)$ for Spain, with the English and Spanish league consisting of 20 teams and the German and Italian leagues consisting of 18 teams, like the Dutch league. This would imply that the total number of manager separations in the Netherlands is not unusual. The only noteworthy observation is that the number of forced resignations is higher in all other countries compared to the Netherlands. The difference-in-difference analysis of the pooled set of the four leagues is reported in Panel D of Table 2. The control groups are defined in the same way as in the Dutch case and survive the tests for uniformity across teams. The number of performance dips for each of the three control groups are 47, 52, and 54 respectively. The results in Panel D suggest that the same conclusion seems to apply to the effect of manager turnover on firm outcomes in these leagues. Again, there seems to be an immediate positive effect of appointing a new manager, which goes away after about three games. What could be read from Panel $\mathrm{D}$ is that the coefficients are more modest than the ones for the Dutch league, but in terms of significance they are not very different.

For Germany Grüne (2000) has documented 250 forced resignations since the beginning of the 1.Bundesliga in 1963. These resignations come with a one-page description of the manager's time at the club and the league position at the time of arrival and departure. Of these observations 212 resignations can be used because they have taken place within the same league. From these descriptions the mean (standard deviation) tenure equals 20.231 (17.162) months and the mean difference between the league positions when taking over and when leaving is equal to -1.052 (4.785). The relationship between tenure and the difference in league position, controlling for the league position when the manager is appointed, equals $0.028(0.016)$, which is significant at the 10 percent level. It implies that a one standard deviation increase in tenure increases the difference between the initial and final league position by about 10 percent. Finally, it is interesting to observe that 12.3 percent of the managers are sacked at the same league position at which they have been appointed and that 30.6 percent of the managers are sacked within two league positions (plus or minus) of the position at which they were appointed. This observation suggests that 43 percent of the population of sacked managers in the German soccer league has performed by and

\footnotetext{
5 For both these control groups the test of uniformity cannot be rejected.
} 
large similar to their predecessors. These results seem to be consistent with the numbers presented in the Appendix and in Table 1, which suggest that team performance is relatively stable over time and that manager characteristics do not differ to a large extent.

\subsection{Manager Characteristics}

Table 3 presents probit estimates of manager characteristics on the probability of manager turnover for managers who experience performance dips. The set of control variables is the one highlighted in Table 1. The model estimated is the following $T_{i}^{*}=\alpha X_{i}+\varepsilon_{i}$ with $T_{i}=1$ if $T_{i}^{*}>0$ and 0 otherwise. $X_{i}$ are manager characteristics and $\varepsilon_{i}$ is an error term with the usual assumptions. The estimates suggest that the total number of players bought by the present manager, which is a measure of firm investments, increases the probability that a manager is sacked during a performance dip. Two other significant results are that a longer time left on the current contract reduces the probability of forced manager turnover, which could be interpreted as boards still having confidence in the manager experiencing a performance dip with his team or that the sacking of the manager is too expensive if his contract length is still substantial. The other result is that tenure with the firm reduces the probability of manager turnover, which implies that the board takes into account the manager's past performance and expects him to turn things around during a dip.

When the control group is changed according to the two alternative definitions presented in the section above, the qualitative implications of the estimates do not change and the coefficients only marginally so. Also, the indicators of manager quality, such as experience as a manager and being a former (top) player do not seem to be good predictors for manager turnover. This seems to suggest that manager quality does not matter in predicting manager turnover and success, which tends to support the view that managers are generally not able to influence firm outcomes and only play a role in the process of mean reversion after a performance dip.

The remaining contract length seems to be a good indicator to predict turnover. When the analysis is restricted to a subset of managers whose contract ends at the end of the season in which the performance dip occurs and/or managers who are in their second year or later with the firm, an insignificant negative coefficient is obtained. This suggests that it might indeed be too expensive to sack a manager when contract length is still substantial.

\subsection{Firm Expectations}

An alternative way to look at the data is to focus on deviations from expected performance, rather than performance alone. It has been argued that boards focus on these deviations in making manager turnover decisions (e.g., Farrell and Whidbee 2003). In the second column of Table 3 two variables are added to indicate the present league position during the dip and the difference between the average final league position of the 3 years before the dip and the present league position to signal the deviation from the expected performance. For the same purpose, the results in column (3) show 
Table 3 The likelihood of manager turnover (dependent variable: probability of forced resignation)

\begin{tabular}{|c|c|c|c|}
\hline & $(1)$ & (2) & (3) \\
\hline Experience as a manager (years) & $\begin{array}{l}-0.021 \\
(-0.408)\end{array}$ & $\begin{array}{l}-0.014 \\
(-0.362)\end{array}$ & $\begin{array}{l}-0.015 \\
(-0.378)\end{array}$ \\
\hline Playing career as soccer player (dummy variable) & $\begin{array}{l}-0.007 \\
(-0.132)\end{array}$ & $\begin{array}{l}-0.008 \\
(-0.125)\end{array}$ & $\begin{array}{l}-0.007 \\
(-0.127)\end{array}$ \\
\hline Played for country (dummy variable) & $\begin{array}{l}-0.034 \\
(-0.687)\end{array}$ & $\begin{array}{l}-0.032 \\
(-0.629)\end{array}$ & $\begin{array}{l}-0.032 \\
(-0.637)\end{array}$ \\
\hline Attacking player (dummy variable) & $\begin{array}{l}0.039 \\
(0.738)\end{array}$ & $\begin{array}{l}0.027 \\
(0.702)\end{array}$ & $\begin{array}{l}0.033 \\
(0.731)\end{array}$ \\
\hline Number of spells during career & $\begin{array}{l}0.062 \\
(1.458)\end{array}$ & $\begin{array}{l}0.071 \\
(1.522)\end{array}$ & $\begin{array}{l}0.060 \\
(1.388)\end{array}$ \\
\hline Tenure with club (days) & $\begin{array}{l}-0.054 \\
(-1.892)^{*}\end{array}$ & $\begin{array}{l}-0.052 \\
(-1.811)^{*}\end{array}$ & $\begin{array}{l}-0.054 \\
(-1.887)^{*}\end{array}$ \\
\hline Total number of players bought during spell at one club & $\begin{array}{l}0.062 \\
(1.929)^{* *}\end{array}$ & $\begin{array}{l}0.053 \\
(1.902)^{* *}\end{array}$ & $\begin{array}{l}0.075 \\
(1.996)^{* *}\end{array}$ \\
\hline Remaining contract length when leaving (days) & $\begin{array}{l}-0.173 \\
(3.994) * *\end{array}$ & $\begin{array}{l}-0.145 \\
(2.140)^{* *}\end{array}$ & $\begin{array}{l}-0.157 \\
(3.257)^{* *}\end{array}$ \\
\hline Present league position & & $\begin{array}{l}0.013 \\
(1.925)^{*}\end{array}$ & \\
\hline $\begin{array}{l}\text { Difference between average of last } 3 \text { years and } \\
\text { present league position }\end{array}$ & & $\begin{array}{l}-0.075 \\
(3.281)^{* *}\end{array}$ & \\
\hline Present average number of points during season & & & $\begin{array}{l}-0.052 \\
(1.569)\end{array}$ \\
\hline $\begin{array}{l}\text { Difference between average of last } \\
3 \text { years and average number of points }\end{array}$ & & & $\begin{array}{l}0.084 \\
(3.005)^{* *}\end{array}$ \\
\hline$n$ & 293 & 293 & 293 \\
\hline
\end{tabular}

The coefficients are odds ratios with asymptotic $t$-statistics. A * indicates that a coefficient is significant at the 10 percent level, $* *$ at the 5 percent level

estimates using the average number of points per game in the present season and the difference of the average number of points per game in the last 3 years and the present average number of points per game.

The estimates suggest that a lower present league position (the variable is measured from 1 to 18 , with 1 being the best and 18 being the worst) increases the probability of turnover during a performance dip. More importantly, a larger difference between the expected and realized league position during a dip increases the probability of manager turnover substantially. Similar results are obtained when using the average number of points instead of league position. These results are consistent with the results obtained by Farrell and Whidbee (2003) for a sample of large publicly traded U.S. firms. They report estimates suggesting that deviations from expected performance are important 
determinants of manager turnover. The results in Table 3 also suggest that the effects of tenure with the firm, the number of players bought and the remaining years left on the present contract remain good predictors of manager turnover during performance dips.

\subsection{SLS Estimates of Performance Recovery}

The estimates in Table 3 can be viewed as the first stage regression results of an analysis in which the forced resignations are regressed on performance changes after manager turnover. ${ }^{6}$ The problem with estimating this relationship is that it is unknown whether manager turnover helps to improve firm outcomes because it is unknown what would have happened if the manager had been allowed to stay. In addition, the firm's board has inside information about a manager and is likely to take into account this information when deciding upon the manager's future with the firm in case of a performance dip. The remaining contract length seems to be a good instrument for forced resignations, since it correlates negatively with the probability of being sacked and is independent of experiencing a performance dip.

In Table 4 OLS and 2SLS estimates of manager characteristics and a dummy variable for forced resignation on performance change $(P)$ between $t+1$ and $t+4$ are estimated for managers experiencing a performance dip: $P_{t 4-t 1}=\alpha_{1} X_{i}+\alpha_{2} T_{i}+\varepsilon_{i}$. In this equation $T_{i}$ is instrumented by the remaining time left on the current contract in the 2SLS estimates, and $X_{i}$ includes all other manager characteristics. The first row in column (1) reports the coefficient of OLS estimates for $T_{i}$ on $P_{t 4-t 1}$ without any control variables. In the next row the set $X_{i}$ is added and the third and fourth rows report the estimate for $T_{i}$ when firm expectations are added. All four estimates for $T_{i}$ suggest, in line with Fig. 2, that there is a negative relationship between sacking the manager and performance recovery after manager turnover compared to a control group of managers who have been allowed to stay with the firm.

In column (2) the 2SLS equivalent is reported. What is striking is that the coefficients change sign from strongly negative to positive, although not significant. The positive sign implies that forced manager turnover is improving firm outcomes compared to a control group in which managers are not sacked. The next two panels report the same estimates for a less strict control group, equivalent to the ones defined in Sect. 4.1 and reported in Table 2 above. Again the sign of the coefficients switches when moving from OLS to 2SLS, but the estimates are not significant. In column (3) similar estimates are reported for a different performance change, namely from one game prior to resignation to four games after resignation. The results of this alternative measure are similar.

Overall, these estimates suggest that OLS estimates are biased and that it is likely that firms are using more information than merely performance indicators to decide to sack a manager. More importantly, the 2SLS estimates suggest that, relative to different definitions of the control group of firms, firm outcomes do not significantly improve after manager turnover although the coefficient is positive.

\footnotetext{
6 To be more precise, it is actually the linear version of the probit equation.
} 
Table 4 Manager turnover and firm outcomes (dependent variable: performance changes after resignation)

\begin{tabular}{|c|c|c|c|}
\hline \multirow[t]{3}{*}{ Performance changes } & (1) & (2) & (3) \\
\hline & OLS & 2SLS & 2SLS \\
\hline & $P_{t 4-t 1}$ & $P_{t 4-t 1}$ & $P_{t 4-(t-1)}$ \\
\hline \multicolumn{4}{|l|}{$\begin{array}{l}\text { Baseline control group (Four-game } \\
\text { decline of max. } 25 \text { percent, } \\
\text { performance at min. } 75 \text { percent of } \\
\text { season's average) }\end{array}$} \\
\hline No additional controls & $-0.406(0.072)^{* *}$ & $0.333(0.425)$ & $0.221(0.448)$ \\
\hline All controls & $-0.473(0.073)^{* *}$ & $0.330(0.500)$ & $0.275(0.561)$ \\
\hline All controls and expectations of league position & $-0.472(0.074)^{* *}$ & $0.338(0.521)$ & $0.284(0.569)$ \\
\hline $\begin{array}{l}\text { All controls and expectations of average } \\
\text { number of points }\end{array}$ & $-0.482(0.074)^{* *}$ & $0.339(0.536)$ & $0.299(0.521)$ \\
\hline \multicolumn{4}{|l|}{$\begin{array}{l}\text { Control group } 2 \text { (Four-game decline of } \\
\text { max. } 25 \text { percent, performance at min. } \\
65 \text { percent of season's average) }\end{array}$} \\
\hline No additional controls & $-0.389(0.071)^{* *}$ & $0.420(0.369)$ & $0.265(0.385)$ \\
\hline All controls & $-0.416(0.073)^{* *}$ & $0.428(0.372)$ & $0.271(0.388)$ \\
\hline All controls and expectations of league position & $-0.418(0.072)^{* *}$ & $0.429(0.375)$ & $0.272(0.383)$ \\
\hline $\begin{array}{l}\text { All controls and expectations of average } \\
\text { number of points }\end{array}$ & $-0.419(0.071)^{* *}$ & $0.439(0.379)$ & $0.273(0.383)$ \\
\hline \multicolumn{4}{|l|}{$\begin{array}{l}\text { Control group } 3 \text { (Four-game decline of } \\
\text { max. } 35 \text { percent, performance at min. } \\
65 \text { percent of season's average) }\end{array}$} \\
\hline No additional controls & $-0.345(0.070)^{* *}$ & $0.458(0.352)$ & $0.308(0.352)$ \\
\hline All controls & $-0.358(0.071)^{* *}$ & $0.463(0.365)$ & $0.317(0.355)$ \\
\hline All controls and expectations of league position & $-0.360(0.072)^{* *}$ & $0.463(0.364)$ & $0.319(0.356)$ \\
\hline $\begin{array}{l}\text { All controls and expectations of average } \\
\text { number of points }\end{array}$ & $-0.368(0.070)^{* *}$ & $0.469(0.368)$ & $0.333(0.358)$ \\
\hline
\end{tabular}

Robust standard errors are reported in brackets. $* * 5$ percent level. The reported coefficients are the estimates for the forced resignation dummy variable. In the 2SLS estimates, the remaining contract length instruments this dummy

\section{Putting the Results into Perspective}

The results from the analysis are clear now but need to be put into perspective. This is done by considering the relation to the literature in three parts. First, a link is established between the estimates in this paper and estimates presented in the business literature. Second, the relevance of manager quality is viewed from the perspective of the estimates presented here and elsewhere. Finally, the estimates are related to other estimates from the sports economics literature on the effects of manager turnover on team performance.

\subsection{Manager Turnover and Firm Outcomes}

There are a relatively large number of studies investigating the relationship between manager turnover and firm outcomes. The first category looks at stock prices as a 
measure of firm performance and basically investigates changes in stock prices before and after manager turnover. Coughlan and Schmidt (1985) made the first notable contribution in the empirical economic literature on the effect of manager turnover on firm performance. ${ }^{7}$ They show that the threat of turnover in case of disappointing stock prices is used to control the manager using a small sample of U.S. firms for the period 1977-1980. ${ }^{8}$ Since then many studies have focused on firm outcomes in case of forced manager turnover. Most studies agree that the likelihood of manager turnover increases if firms are doing relatively poorly.

It is however not so clear what happens to firm performance after managers have been replaced. Some studies have used stock price reactions around turnover, but this is an indicator of market beliefs about the effects of manager turnover, not the actual effect on firm performance. Others have taken into account firm structure (Denis et al. 1997), take-over threats (Huson et al. 2001), firm expectations (Farrell and Whidbee 2003), and the composition of top executive teams (Fee and Hadlock 2004) as predictors of top manager turnover. Generally, the magnitude of the effects on firm outcomes is relatively small but positive and significant. For example, Denis and Denis (1995) report estimates of the determinants of turnover from a sample of 908 firms in the period 1985-1988 implying that after forced resignation the firm did better afterwards. Huson et al. (2004) extend this study to a longer time period (1971-1995) and solve some of the potential methodological and econometric problems the Denis-Denis study suffers from. They find that forced turnovers are preceded by poor performance and followed by significant improvements in firm performance in terms of operation returns.

The estimates reported in the present paper suggest that manager turnover does not improve firm performance significantly relative to three differently defined control groups. There are a number of reasons for the contrasting results between studies applying business firm data and the present estimates. First, the measures of firm performance in the business literature are not without discussion. Stock prices around the time of manager turnover are not the right measure for real outcomes but only reveal expectations. In addition, the operating income to book assets (OROA) or to sales (OROS) is often an industry specific measure of firm performance. Some authors have adjusted their data for industry effects but they remain controversial (see e.g. Barber and Lyon 1996). Soccer outcomes are measured directly and on a weekly basis and are not surrounded by any uncertainty or measurement error. Another point worth making is that the firm outcomes are available in very short time intervals in the soccer data. This is an advantage since managers are often released during the year, whereas for business firm data the years prior to resignations have to be compared to the years after resignation in which other things than the position of the CEO change as well. This is one of the reasons for many authors to have investigated firms' stock prices

\footnotetext{
7 Earlier studies have mostly focused on the relationship between executive pay and performance. These studies will not be considered here.

8 Early papers by Klein and Rosenfeld (1988), Warner et al. (1988) and Weisbach (1988) find weak evidence in favor of an inverse relationship between a firm's stock returns and subsequent top management changes, particularly for companies with outsider-dominated boards and for companies with strong monitoring policies.
} 
on a daily basis around the time of manager turnover. Finally, the soccer league comprises one industry, which makes the comparison across firms easier. Indeed, Parrino (1997) finds that performance is easier to monitor in homogeneous industries, which makes the identification of poor management easier and less costly to observe and replace.

\subsection{Does Manager Quality Matter for Firm Outcomes?}

The estimates presented above suggest that manager quality measured by the manager's previous achievements as a player, years of managerial experience and number of spells does not significantly matter for predicting turnover and does not explain much of the performance increase after resignation. Recent studies using business data carried out by Bertrand and Schoar (2003) for the United States and Bloom and Van Reenen (2007) for a large number of other countries suggest that manager quality does make difference and that differences in manager quality explain a significant portion of firm heterogeneity in among others firm performance.

There are three explanations for the obtained differences. First, most studies about manager quality do not look at manager turnover and not at all at forced turnover. For example, Bertrand and Schoar (2003) look at manager-firm pairs and estimate whether manager fixed effects can explain differences in firm outcomes. This difference in terms of focus can explain at least part of the difference in findings. Second, the focus in the present paper is on the top soccer league in which only 18 managers can be employed at the same time. This small market is likely to be characterized by a large supply of potential managers, which drives up quality and lowers the standard deviation of average manager quality. Finally, manager characteristics and quality are easily observed in the soccer market. In business firms, experience, number of spells, education etc. are surrounded with much more heterogeneity. For example, it matters whether a manager has working experience with a large high-valued publicly traded firm instead of a small privately owned firm. Also, the years of education do not seem to matter and differ not that much between managers. But, having a MBA degree from a top ten university is certainly more valued than a degree from another university. These effects are easier observed in the soccer data. In this paper it has been measured by means of managers having had a top player career, having been a professional player at all, and by the type of player the manager used to be. Finally, soccer managers' decisions concerning firm investments are directly observed by means of the number of players bought and sold. These investments are likely to become effective soon relative to the long-term strategies of business firm managers.

\subsection{Evidence from Other Analyses Using Sports Data}

This paper is not the first examining the impact of manager turnover on subsequent team outcomes in sports, and in particular in soccer. ${ }^{9}$

\footnotetext{
${ }^{9}$ Here the focus is limited to research on soccer teams. Brown (1982) uses data from American football (the NFL) in the period 1970-1978 to assess the impact of manager turnover on team performance. His
} 
For the Netherlands, Van Dalen (1994), Koning (2003) and Bruinshoofd and Ter Weel (2003) have performed similar types of empirical investigations. Van Dalen (1994) uses data for the 1993/94 season only. He estimates a model in which he tries to explain the difference between the goals scored. The covariates are measures of referee quality, team quality and performance in the previous game. Also included is a dummy variable indicating whether or not the game is a home game and a trend variable. Most importantly, he includes a dummy variable that indicates whether or not a new manager has taken over during the season. His estimates reveal that manager turnover during the 1993/94 season has a positive effect on the goal difference. Koning (2003) focuses on forced resignations only during five seasons in the period 1993-1998. The dependent variable in his analysis is similar to the one used by Van Dalen (1994). He improves upon the analysis by Van Dalen by controlling for programme effects, because the model used for the goal difference depends on the ranking of both teams at the moment the game is played. This way he controls for the differences in the quality of the opponents faced by the new and old manager. His estimates reveal that team performance does not always improve when a manager has been forced to resign. In most cases, new coaches perform worse than their fired predecessors. So, Koning extends the findings and analysis of Van Dalen (1994). He also shows that the 1993/94 season is an outlier. The main difference with the present paper is that Koning (2003) and Van Dalen (1994) focus on much shorter time periods and use a measure of team performance that is much more volatile compared to the one used here. The advantages of our measure of team performance are discussed in Sects. 3.2 and 3.3. Also the estimation methodology is different, since they do not construct a control group to execute a difference-in-difference analysis. Basically they only apply a before-after analysis on goals scored.

Bruinshoofd and Ter Weel (2003) apply the same methodology as used in this paper. They focus on twelve soccer seasons in the period 1988-2000, whereas the present paper considers the period 1986-2004. In addition, Bruinshoofd and Ter Weel (2003) do not consider measures of managerial background and investments. They only focus on a difference-in-difference analysis and find, similar to the findings in this paper, that forced resignations do not significantly improve team performance. Bruinshoofd and Ter Weel (2003) also show that a before-after analysis is insufficient to pinpoint the effects of manager turnover. The reason is the appearance of Ashenfelter's dip in team performance before and after resignation.

In Sect. 4.1.2 the results of a brief analysis conduced for four other countries have been described. More advanced empirical analysis has been carried out by Frick and Simmons (2008) for Germany, by De Paola and Scoppa (2008) for Italy and by Audas et al. (1999) for England. Dawson et al. (2000) review the literature for England and argue that it is important to take into account measures of manager quality and history. All papers use a different methodology and have a somewhat different focus. However, they all contain estimates of the effects of manager turnover on team performance.

estimates reveal that the costs are higher than the benefits in terms of games won before and after turnover. Scully (1995) examines the effects of manager turnover on team performance in baseball and basketball. The measure of turnover applied in that analysis is one of turnover in between seasons. 
Frick and Simmons (2008) are interested in explaining the effect of managerial quality on team performance in Germany in the period 1981-2003. Managerial quality is measured by the manager's salary and his past performance. In terms of the effects of manager turnover during a season they find that it does not improve team performance, which is consistent with the findings in this paper. De Paola and Scoppa (2008) use the methodology of Bruinshoofd and Ter Weel (2003) to assess the impact of manager turnover in Italy during five seasons (2003-2008). They confirm the estimates for the Netherlands that team performance does not improve after forced resignation. Audas et al. (1999) estimate hazard functions for involuntary and voluntary managerial turnover for English professional soccer for the period 1972-1997. Their data contain over nine hundred manager spells and reveal an increase in manager turnover over time. The estimates suggest that short-term fluctuations in team performance increase the probability of forced resignation. They do not address whether performance improves after a new manager is appointed. Overall, these studies confirm the findings in the present paper that forced manager turnover in soccer does not improve team performance.

\section{Conclusion}

This research has examined the effects of manager turnover on firm performance for a unique set of firms over a relatively long period of time. The results fall in a body of literature that is relatively large and becoming larger over the last couple of years (see the previous section for a discussion). The general interest of the results presented here is that using data from sports - in this case the Dutch soccer league — sheds light on the different results obtained in many studies using (publicly traded) firms to assess to effects of manager turnover on firm outcomes. In particular this study has shown three main things.

First, using difference-in-difference estimates and a 2SLS strategy, it has been shown that manager turnover is not followed by significant improvements in firm performance and that manager quality does not seem to predicted manager turnover. These results are robust to different specifications. Second, the results have been compared and contrasted with estimates from the business literature on manager turnover and firm performance. The conclusion from this comparison is that the ability to observe firm outcomes and manager decisions directly is a main advantage reducing heterogeneity and noise in the data. Finally, the estimates are in line with the evidence found in other studies and for other countries using sports data to assess the effects of manager turnover on firm performance.

\section{Appendix: The Dutch Soccer League}

The highest professional soccer league in the Netherlands (Eredivisie) consists every year of 18 teams. The composition of the league changes from year to year because of promotion from and relegation to the second division.

The data consist of teams, which played in the highest league during at least nine seasons between $1986 / 87$ and 2003/04. The main reason for doing so is that infor- 
mation about these firms is most accurate and complete. There is no manager information available for relegated teams and for teams playing only occasionally in the Eredivisie, which makes the computation of spells hard and yields problems of censoring.

The 19 teams in the data all have completed manager spells and are in alphabetical order Ajax, AZ, De Graafschap, FC Groningen, FC Twente, FC Utrecht, FC Volendam, Feyenoord, Fortuna Sittard, MVV, NAC, NEC, PSV, RKC Waalwijk, Roda JC, SC Heerenveen, Sparta, Vitesse and Willem II. The first column in Table 5 presents the teams and in brackets the number of seasons a team has been present in the Eredivisie and hence is present in the database.

During one league season each team has to play every other team twice (once at home and once away), so that the total number of games for each team during a season is 34 . For each win a team receives three points, a draw gives one point, and a loss no points. From 1995 on the 3-1-0 points rule is effective. Before 1995 the rule was 2-1-0. For ease of comparison, I use throughout this paper the 3-1-0-rule for all years. The ranking of teams does only marginally change when I rely upon the 3-1-0-rule instead of relying upon the 2-1-0-rule. The most important change is that PSV would have been the 1989/1990 champions instead of Ajax. Also, for the measurement of performance dips the rule turns out to be unimportant. Hence, the end-of-season team scores lie within a range of $0-102$. The next columns in Table 5 present the average number of points per game for each of the 18 seasons in the data. The number in brackets presents the standard deviation and the number in squared brackets is the rank at the end of the season. Empty cells indicate that a team was playing in the second division. For the second division no data are available on managers to compile a consistent set of manager careers.

Every season the team ending 18th relegates to the second division and the winner of the second division (Eerste Divisie) is promoted to the Eredivisie. The teams ranking 16th and 17th in the Eredivisie have to play a competition of promotionrelegation playoff games in a small four-team competition with the teams that have finished 2nd to 7th in the Eerste Divisie. Both Eredivisie teams are in a different competition. The two winners of the competitions are allowed to play in the Eredivisie in the next season. The others play in the Eerste Divisie. In most instances the Eredivisie teams win these competitions as can be seen from the teams finishing 16th or 17th in Table 5 and their presence in the data in the next season. (See Table 5)

Acknowledgements I wish to thank Gertjan van den Berg for providing excellent research assistance. I am also very grateful to Infostrada BV, and in particular to Wouter Smak, for access to and help with collecting the data on manager turnover and manager characteristics; and to the Netherlands Organization for Scientific Research (NWO) and the Maastricht Research School of Economics of Technology and Organizations (METEOR) for financial support. Finally, I wish to thank the two referees of this journal, Lex Borghans and Allard Bruinshoofd for providing very useful comments on an earlier version of this paper.

Open Access This article is distributed under the terms of the Creative Commons Attribution Noncommercial License which permits any noncommercial use, distribution, and reproduction in any medium, provided the original author(s) and source are credited. 


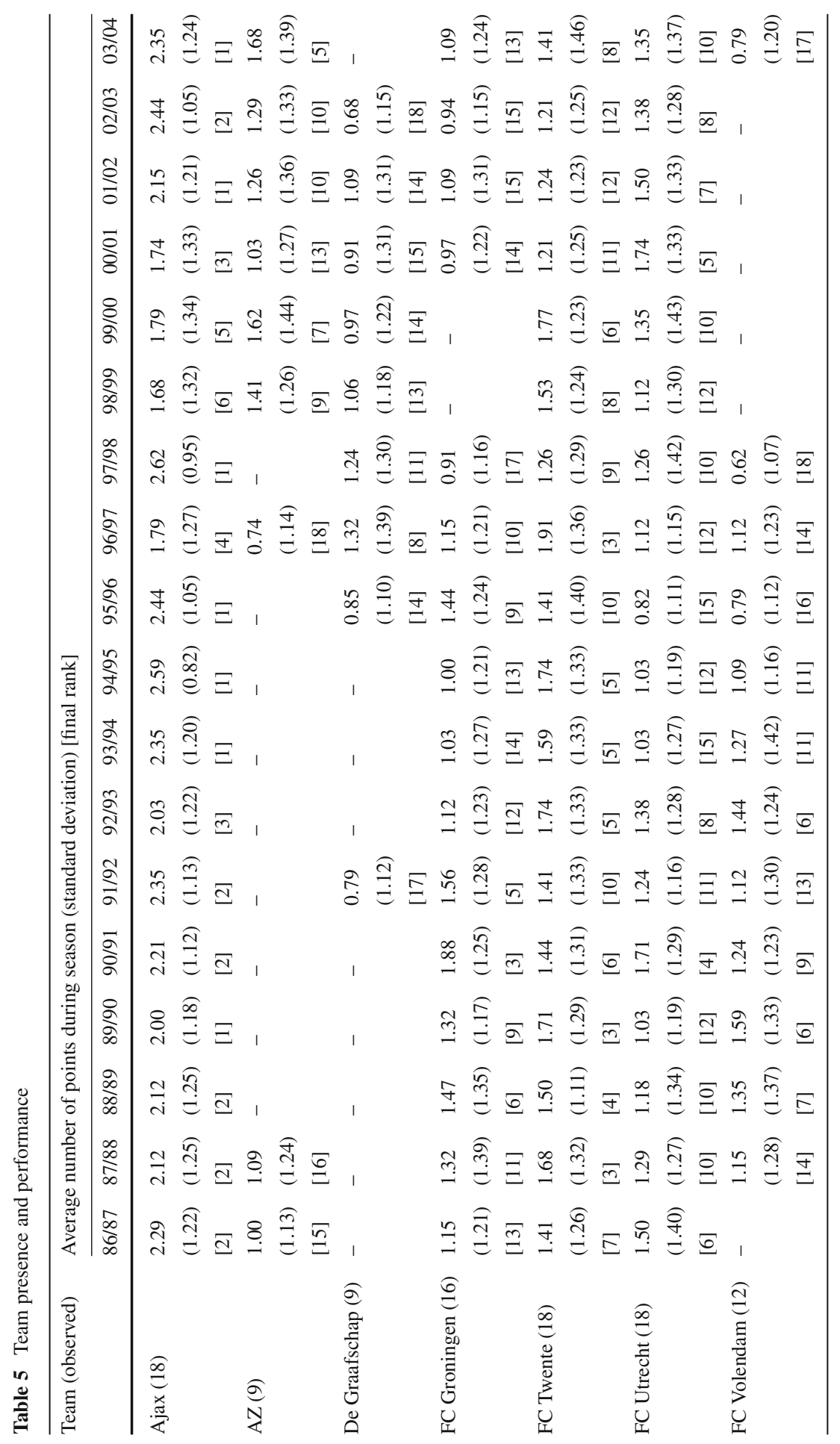




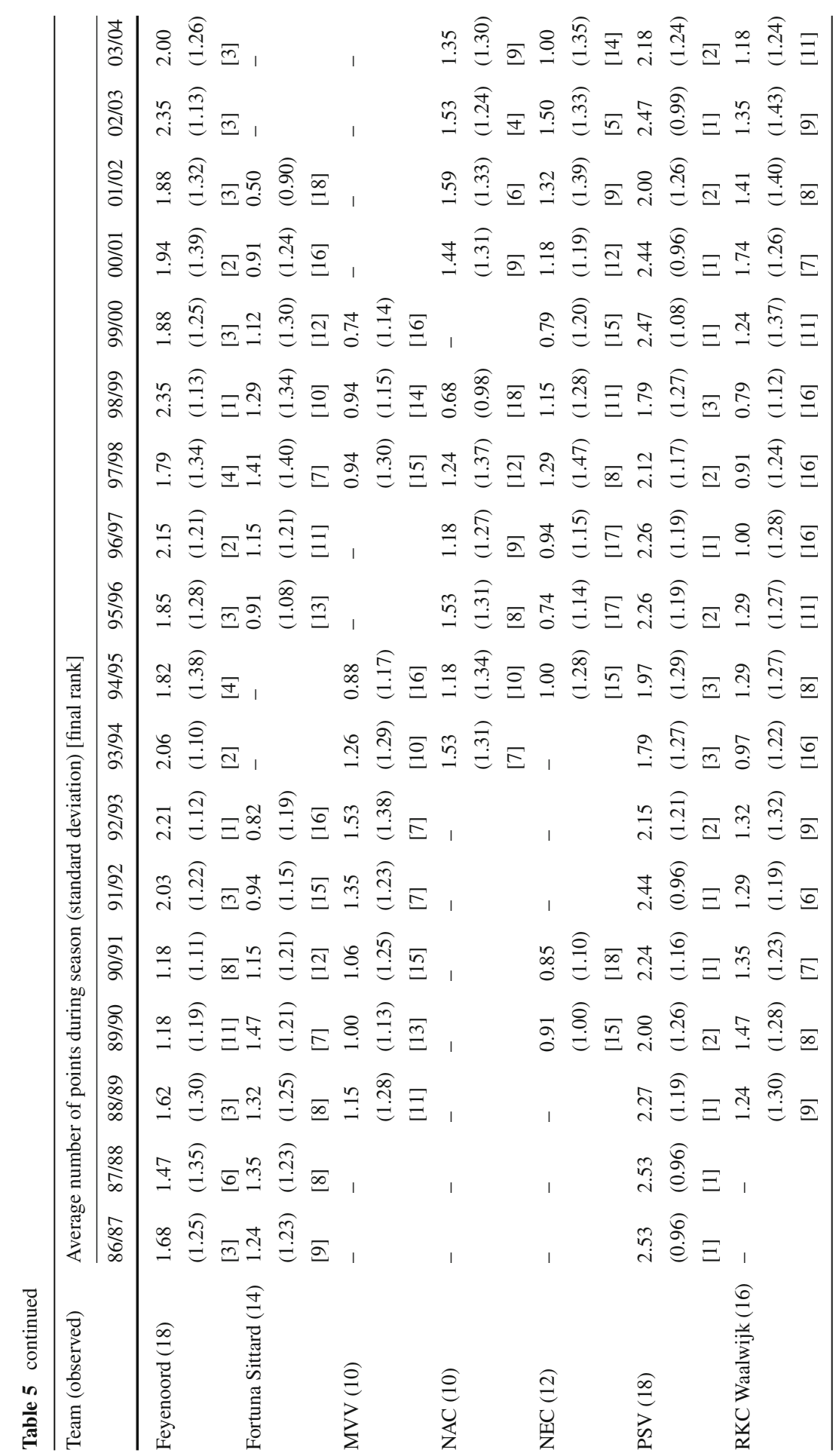




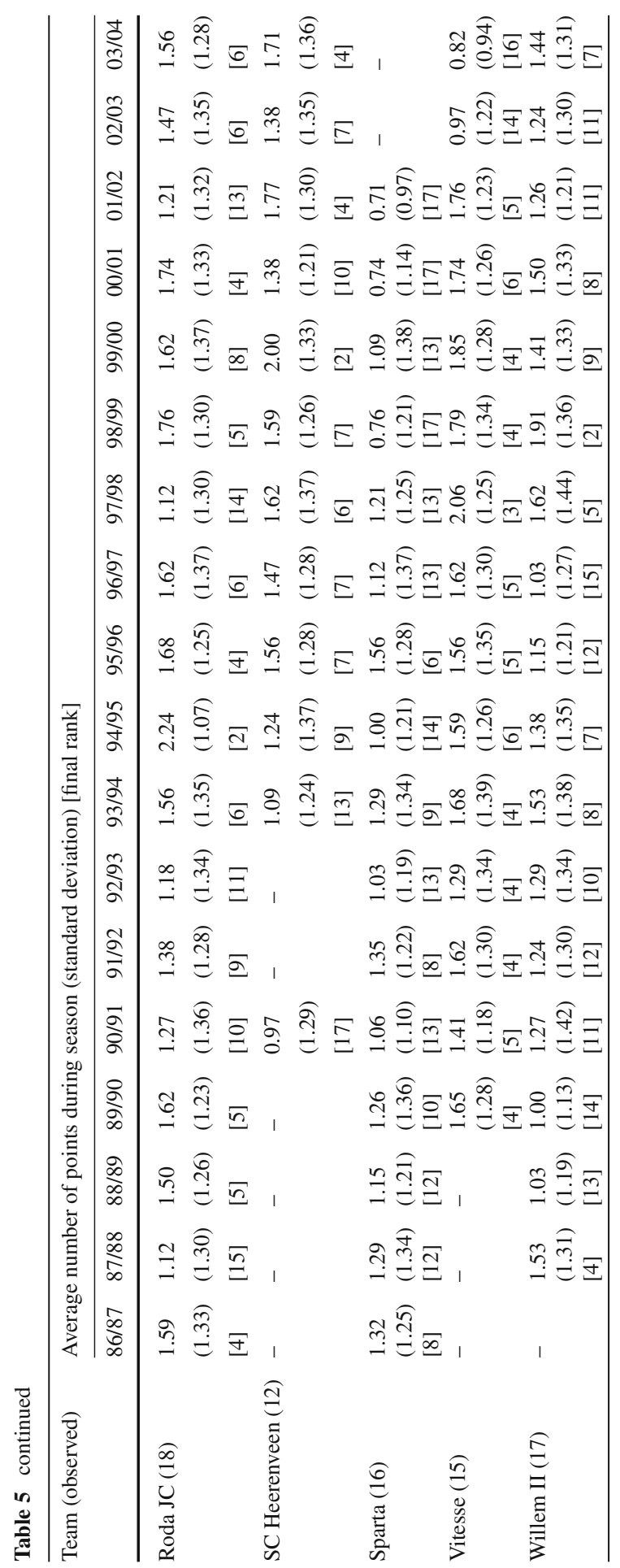




\section{References}

Audas, R., Dobson, S., \& Goddard, J. (1999). Organizational performance and managerial turnover. Managerial and Decision Economics, 20(6), 305-318.

Barber, B. M., \& Lyon, J. D. (1996). Detecting abnormal operating performance: The empirical power and specification of test statistics. Journal of Financial Economics, 41(2), 359-399.

Bertrand, M., \& Schoar, A. (2003). Managing with style: The effect of managers on firm policies. Quarterly Journal of Economics, 118(4), 1169-1208.

Bloom, N., \& Van Reenen, J. (2007). Measuring and explaining management practices across firms and nations. Quarterly Journal of Economics, 122(4), 1351-1408.

Brown, M. C. (1982). Administrative succession and organizational performance: The succession effect. Administrative Science Quarterly, 27(1), 1-16.

Bruinshoofd, A., \& ter Weel, B. (2003). Manager to go? Performance dips reconsidered with evidence from Dutch football. European Journal of Operational Research, 148(2), 233-246.

Coughlan, A. T., \& Schmidt, R. M. (1985). Executive compensation, management turnover, and firm performance: An empirical investigation. Journal of Accounting and Economics, 7(1-3), 43-66.

Dawson, P., Dobson, S., \& Gerrard, B. (2000). Estimating coaching efficiency in professional team sports: Evidence from english association football. Scottish Journal of Political Economy, 47(4), 399-421.

Denis, D. J., \& Denis, D. K. (1995). Performance changes following top management dismissals. Journal of Finance, 50(4), 1029-1057.

Denis, D. J., Denis, D. K., \& Sarin, A. (1997). Ownership structure and top executive turnover. Journal of Financial Economics, 45(1), 193-221.

De Paola, M., \& Scoppa, V. (2008). The effects of managerial turnover: Evidence from coach dismissals in Italian soccer teams. MPRA Paper No. 11030.

Farrell, K. A., \& Whidbee, D. A. (2003). Impact of firm performance expectations on CEO turnover and replacement decisions. Journal of Accounting and Economics, 36(1-3), 165-196.

Fee, C. E., \& Hadlock, C. J. (2004). Management turnover across the corporate hierarchy. Journal of Accounting and Economics, 37(1), 3-38.

Frick, B., \& Simmons, R. (2008). The impact of managerial quality on organizational performance: Evidence from German soccer. Managerial and Decision Economics, 29(7), 593-600.

Grüne, H. (2000). Geheuert, Gefeiert, Gefeuert: Die 250 Vorzeitigen Trainerwechsel der Bundesligageschichte Seit 1963. Agon: Sportverlag.

Huson, M. R., Parrino, R., \& Starks, L. T. (2001). Internal monitoring mechanisms and CEO turnover: A long term perspective. Journal of Finance, 56(6), 2265-2297.

Huson, M. R., Malatesta, P. H., \& Parrino, R. (2004). Managerial succession and firm performance. Journal of Financial Economics, 74(1), 237-275.

Khanna, N., \& Poulson, A. B. (1995). Managers of financially distressed firms: Villains or scapegoats. Journal of Finance, 50(4), 919-940.

Klein, A., \& Rosenfeld, J. (1988). Targeted share repurchases and top management changes. Journal of Financial Economics, 20(1), 493-506.

Koning, R. H. (2003). An econometric evaluation of the effect of firing a coach on team performance. Applied Economics, 35(5), 555-564.

Malmendier, U., \& Tate, G. (2009). Superstar CEOs. Quarterly Journal of Economics, 124(4), 1593-1638.

Parrino, R. (1997). CEO turnover and outside succession a cross-sectional analysis. Journal of Financial Economics, 46(2), 165-197.

Scully, G. W. (1995). The market structure of sports. Chicago, IL: University of Chicago Press.

Van Dalen, H. P. (1994). Loont Het om een Voetbaltrainer te Ontslaan. Economisch Statistische Berichten, 79(3987), 1089-1092.

Warner, J. B., Watts, R. L., \& Wruck, K. H. (1988). Stock prices and top management changes. Journal of Financial Economics, 20(1), 461-492.

Weisbach, M. S. (1988). Outside directors and CEO turnover. Journal of Financial Economics, 20(1), 432460 . 